\title{
Attitude of Indian Medical Fraternity Towards Body Donation - A Cross Sectional Survey
}

\author{
Darshna Gulabrao Fulmali1, Preeti Prabhakarrao Thute ${ }^{2}$, Harsha Atul Keche ${ }^{3}$, Vilas Keshavrao Chimurkar ${ }^{4}$ \\ 1, 2, 3, 4 Department of Anatomy, Jawaharlal Nehru Medical College, \\ Sawangi (Meghe) Wardha Maharashtra, India.
}

\section{ABSTRACT}

\section{BACKGROUND}

There is a worldwide scarcity of cadaver for teaching as well as for research. Many private as well as government medical colleges relay only on unclaimed bodies, but this scarcity of cadaver cannot be replenished with the unclaimed bodies alone. Despite the importance of body donation for medical education, cadaveric donation remains suboptimal worldwide. Body donation programs are still in their infancy in our country. The success of these programs depends upon the ability of our health care professionals in motivating the society at large. Thus, it is crucial that our medical fraternity and health care professionals themselves support and favour this issue. Hence this study was carried out to know the attitude of medical fraternity towards body donation program.

\section{METHODS}

A cross-sectional survey was conducted among the faculties of Jawaharlal Nehru Medical College, Sharad Pawar dental college and Ayurvedic college at Datta Meghe Institute of Medical science, Sawangi Meghe, Wardha. Study duration was from July 2018 to July 2019. Inputs from all the study participants were obtained on the basis of questionnaire about the attitude towards body donation after taking their consent. The questionnaire was collected from the participants' and the data obtained was assessed statistically.

\section{RESULTS}

The study revealed significant negative attitude of medical fraternity towards body donation. It was observed that $21.7 \%$ male \& $3.7 \%$ female faculties from medical colleges, $11 \%$ male and $5.71 \%$ female faculties from dental colleges and $25 \%$ male and $10 \%$ female faculties from Ayurvedic colleges were willing for body donation whereas $96 \%$ of faculties from medical colleges, $92 \%$ from dental colleges and $89 \%$ ayurvedic faculties were not willing to donate their bodies for dissection purpose because they had an awful experience in the dissection hall. They had witnessed the dishonoured condition of the cadaver in dissection hall. $95 \%$ of faculties from medical college, $92 \%$ dental faculties and $90 \%$ ayurvedic faculties stated that to get dissected on the table was an atrocious feeling.

\section{CONCLUSIONS}

The success of body donation programs depends upon the ability of health care professionals in motivating the society for voluntary body donation. Negative attitude of medical fraternity towards body donation may interfere with this role. Developing the practice of respecting and honouring the cadaver, from the very beginning of the career will help to change the attitude of medical graduates towards body donation. Competency no AN82.2 from volume 1 UG curriculum, module no 1.5 from ATCOM module may help to change the attitude of budding doctors.

\section{KEY WORDS}

Medical Fraternity, Body Donation, Competency No AN82.2, Module No 1.5
Corresponding Author: Dr. Darshna Gulabrao Fulmali, Sarthak Banglow No. 2, Aditya Residency, Wardha Bypass Road, Sawangi Meghe, Wardha, Maharashtra - 442001, India. E-mail: bhotmagey2010@gmail.com

DOI: $10.14260 /$ jemds/2021/530

How to Cite This Article:

Fulmali DG, Thute PP, Keche HA, et al. Attitude of Indian medical fraternity towards body donation - a cross sectional survey. $J$ Evolution Med Dent Sci 2021;10(32):2587-2591, DOI: 10.14260/jemds/2021/530

Submission 14-10-2020,

Peer Review 07-06-2021,

Acceptance 14-06-2021,

Published 09-08-2021.

Copyright (C) 2021 Darshna Gulabrao Fulmali et al. This is an open access article distributed under Creative Commons Attribution License [Attribution 4.0 International (CC BY 4.0)] 


\section{BACKGROUND}

Dissection of cadaver is the traditional and effective method to teach anatomy to undergraduate as well as postgraduate students of different courses like MBBS, BDS, Ayurvedic, Homeopathy, Unani, Physiotherapy and Occupational therapy. Cadaver is the first teacher of the students. The visual and the tactile experience students get during dissection of cadaver helps in the development of knowledge, skill, and precision. In India, there are few a medical institution which are providing the facility of Cadaveric Skill Lab / Operation Theatres. Medical professionals practice newer and advanced surgical techniques on cadavers to enhance their skills, become competent enough before operating on the living beings. These cadaveric skill laboratories need cadavers. Cadavers are also needed for research work in anatomy, now with the increasing number of medical colleges in the past few years, the need of cadavers has far exceeded, hence there should be adequate inflow of cadavers for health science courses and research activities. There is worldwide scarcity of cadaver for teaching as well as for research.

Rokade SA \& Bahetee BH et al. found a gross insufficiency of cadavers in $90.90 \%$ of medical colleges and $18.18 \%$ of the surveyed colleges did not receive a single cadaver by donation. In the last 5 years. In $63.63 \%$ of these colleges, the number of cadavers available were less than half of the requirement. ${ }^{1}$ At present, unclaimed bodies and few donated bodies are the main source of cadavers that are coming from the authorized government institutions. Many private medical colleges relay only on unclaimed bodies but this scarcity of cadaver cannot be replenished with the unclaimed bodies alone. There came the ideology of "deh - daan" or voluntary body donation. 'Willed body donation' is a must to maintain a constant supply of cadavers for anatomy teaching. Despite the importance of body donation for medical education and the advancement of medical science, cadaveric donation remains suboptimal worldwide. ${ }^{2}$ Voluntary body donation programs are still in their infancy in our country. The success of these programs depends upon the ability of our health care professionals in motivating the society at large. To encourage the public towards body donation we must first develop a positive attitude in medical professionals towards the same. Thus it is imperative that our medical fraternity and health care professionals themselves support and favour this issue. ${ }^{3}$

Hence this study was carried out to know the attitude of medical fraternity towards body donation program.

\section{METHODS}

A cross-sectional survey was carried out at Datta Meghe Institute of Medical Science, Sawangi Meghe, Wardha after taking institutional committee clearance references no DMIMS (DU) / IEC / 2016 - 17 / 3039. Study participants were the faculties from Jawaharlal Nehru medical college, Sharad Pawar dental college, and Ayurvedic college from Dutta Meghe Institute of Medical Science. As the minimum sample size required for any study is 35 and to have an easy comparison, we decided to have a sample of fifty. Fifty faculties from
Jawaharlal Nehru medical college gave their consent. The questionnaire regarding the body donation was validated from professors in the Department of Anatomy. The validated questionnaire about the attitude towards body donation was given to all participants to provide their inputs regarding the same. The questionnaire was collected from the participants' and the data obtained was tabulated.

\section{RESULTS}

Faculties from various departments of medical, dental and ayurvedic colleges were included in the study after taking their consent. It was observed that most of the participants belonged to age group of 41 - 50 years and number of female faculties participating in the study from dental colleges were more as compared to males.

\begin{tabular}{|c|c|c|c|c|c|c|c|c|c|}
\hline $\begin{array}{l}\text { Age / } \\
\text { Gender }\end{array}$ & \multicolumn{3}{|c|}{$\begin{array}{l}\text { Medical College } \\
\text { Male Female }\end{array}$} & \multicolumn{3}{|c|}{$\begin{array}{l}\text { Dental College } \\
\text { Male Female }\end{array}$} & \multicolumn{3}{|c|}{$\begin{array}{l}\text { Ayurvedic College } \\
\text { Male Female }\end{array}$} \\
\hline $\begin{array}{c}30-40 \\
\text { years }\end{array}$ & 7 & 9 & 16 & 8 & 10 & 18 & 8 & 4 & 12 \\
\hline $\begin{array}{l}41-50 \\
\text { years }\end{array}$ & 5 & 7 & 12 & 7 & 11 & 17 & 13 & 15 & 28 \\
\hline $\begin{array}{l}51-60 \\
\text { years }\end{array}$ & 9 & 8 & 17 & 0 & 12 & 12 & 7 & 3 & 10 \\
\hline $\begin{array}{l}61 \text { and } \\
\text { above }\end{array}$ & 2 & 3 & 05 & 0 & 2 & 02 & 0 & 0 & 00 \\
\hline Total & 23 & 27 & 50 & 15 & 35 & 50 & 28 & 22 & 50 \\
\hline \multicolumn{10}{|c|}{ Table 1. Distribution of Study Population } \\
\hline
\end{tabular}

Almost all faculties from Medical (96\%), Dental (86 \%) and Ayurvedic (90\%) colleges were of the opinion that cadaveric dissection was a must to learn anatomy and they had knowledge about the sources of procurement of cadavers. But only faculties from medical colleges (98 \%) were well acquainted about the scarcity of cadaver. All faculties from medical, dental and ayurvedic colleges knew about the body donation program and also believed that awareness about the programme was the need of the hour but very less number of faculties (46\%) medical (46\%) dental (22\%) and ayurvedic participated in any body donation awareness program.

Very less number of faculties $(0 \%, 2 \%, 4 \%)$ witnessed the body donation by their family members. Only $32 \%, 12 \%, 22$ $\%$ faculties from medical, dental and ayurvedic colleges were willing to donate their bodies respectively. Male faculties were more willing than the female faculties for body donation. Number of female faculties (35) willing for donation was more in dental college.

\begin{tabular}{|cccccccc|}
\hline $\begin{array}{c}\text { Willingness of } \\
\text { Faculties } \\
\text { Towards Body } \\
\text { Donation }\end{array}$ & Male & Female & Male & Female & Male & Female \\
Willing & 5 & 1 & 6 & 2 & 7 & 2 \\
Not willing & $(21.7 \%)$ & $(3.7 \%)$ & $(11 \%)$ & $(5.71 \%)$ & $(25 \%)$ & $(10 \%)$ \\
Total & $(78.26 \%)$ & 26 & 11 & 33 & 21 & 20 \\
& $\mathbf{2 3}$ & $\mathbf{2 7} \%$ & $\mathbf{2 7}$ & $\mathbf{1 5}$ & $\mathbf{3 5}$ & $\mathbf{2 8}$ & $\mathbf{2 2}$ \\
\hline \multicolumn{6}{c}{ Table 2. Sex Wise Distribution of Faculties } \\
Willing to Donate Their Bodies \\
\hline
\end{tabular}

The major reason for their willingness for body donation was that they wanted to be useful for medical education and research, the profession that had given them an opportunity to serve humanity after death. 


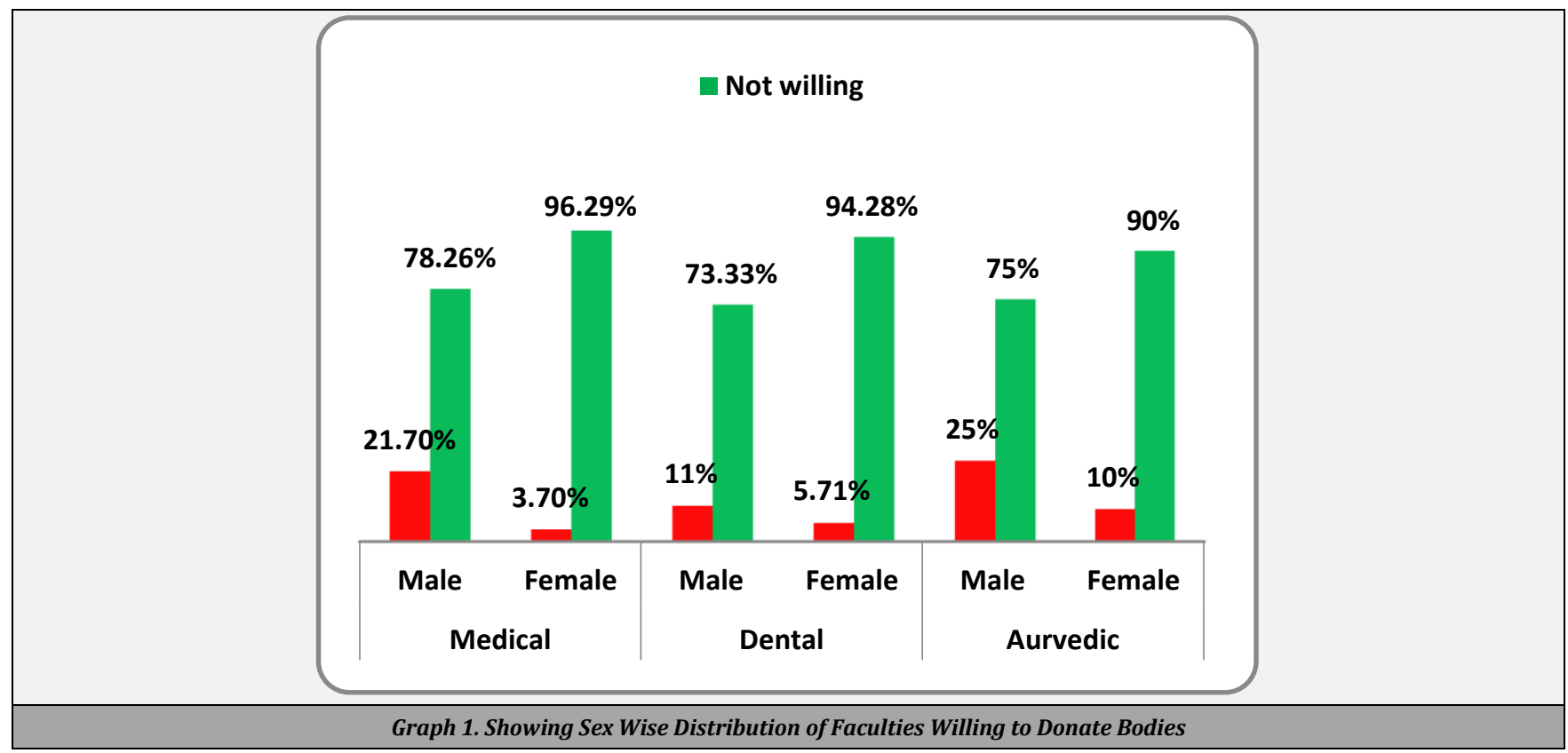

\begin{tabular}{|c|c|c|c|c|}
\hline $\begin{array}{l}\text { Sl. } \\
\text { No. }\end{array}$ & Reasons & $\begin{array}{c}\text { Allopat } \\
\text { hic }\end{array}$ & Dental & Ayurvedic \\
\hline 1 & To donate body is a Nobel altruistic act & $44(88 \%)$ & 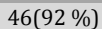 & $43(86 \%)$ \\
\hline 2 & $\begin{array}{l}\text { Initiative taken by medical faculties created } \\
\text { awareness among people for body donation }\end{array}$ & $44(88 \%)$ & $45(90 \%)$ & $42(84 \%)$ \\
\hline 3 & $\begin{array}{l}\text { A small attempt to reduce the scarcity of } \\
\text { cadaver for dissection }\end{array}$ & $45(90 \%)$ & $43(86 \%)$ & $44(88 \%)$ \\
\hline 4 & $\begin{array}{l}\text { Want to be useful for medical education and } \\
\text { research after death }\end{array}$ & $49(98 \%)$ & 49( & $48(96 \%)$ \\
\hline 5 & $\begin{array}{c}\text { As an act of respect for medical profession } \\
\text { who gave an opportunity to live this beautiful } \\
\text { life }\end{array}$ & $49(98 \%)$ & $48(9$ & $48(96 \%)$ \\
\hline \multicolumn{5}{|c|}{ Table 3. Reasons for Willingness of Body Donatic } \\
\hline
\end{tabular}

The most important reasons for non-willingness of body donation among all the faculties were improper handling of the cadaver and disrespectful behaviour by the personnel in the dissection hall. They had seen the cadaver dissected into pieces and they didn't want such a thing to happen with their own bodies. Some religious taboos were also there that prevented them from the act of donation.

\begin{tabular}{|c|c|c|c|c|}
\hline $\begin{array}{l}\text { Sl. } \\
\text { No. }\end{array}$ & Reasons & Allopathic & Dental & Ayurvedi \\
\hline 1 & $\begin{array}{c}\text { My religion doesn't allow me to donate } \\
\text { body }\end{array}$ & $09(18 \%$ & $07(14 \%)$ & $05(10 \%)$ \\
\hline 2 & $\begin{array}{l}\text { It is very atrocious feeling to get } \\
\text { dissected on table }\end{array}$ & \%) & $46(92 \%)$ & $45(90 \%)$ \\
\hline 3 & $\begin{array}{l}\text { I love my body and do } \\
\text { to disrespect it a }\end{array}$ & $33(66 \%)$ & $27(54 \%)$ & $34(64 \%)$ \\
\hline 4 & $\begin{array}{r}\text { I feel my body will } \\
\text { prope }\end{array}$ & $46(92 \%)$ & $38(8$ & 37( \\
\hline 5 & $\begin{array}{r}\text { Had an awful / unplea } \\
\text { dissect }\end{array}$ & $48(96 \%)$ & $46(92 \%)$ & $44(88 \%$ \\
\hline 6 & $\begin{array}{r}\text { The remains of } \\
\text { disposed }\end{array}$ & ( & $38(78 \%)$ & $38(76 \%)$ \\
\hline 7 & $\begin{array}{l}\text { Students does } \\
\text { cadaver for le }\end{array}$ & $80^{-}$ & 33( & 2 \\
\hline 8. & $\begin{array}{r}\text { My family member } \\
\text { donate }\end{array}$ & $11(22$ & $17(34 \%)$ & $15(30 \%)$ \\
\hline 9 & $\begin{array}{l}\text { Cadavers are not respected by the } \\
\text { students }\end{array}$ & 0) & 33 & 16( \\
\hline 10 & $\begin{array}{c}\text { Cadavers are not handled properly by } \\
\text { the staff and students }\end{array}$ & $39(78$ & $24(48 \%)$ & $27(54 \%)$ \\
\hline \multicolumn{5}{|c|}{ Table 4. Reasons for Non-Willingness of Body Donation } \\
\hline
\end{tabular}

\section{DISCUSSION}

Cadaveric dissection is an important and effective method used to learn anatomy. Anatomical models and some anatomy softwares are helpful as well, but the practical experience of handling the tissue during dissection by the students is unique and this experience will help them in future while dealing with the patient's body. With the establishment of new private as well as government medical colleges and increase in their student intake capacity, they are facing the problem of scarcity of cadavers for dissection.

The number of cadavers available per student is important as this will decide the quality of teaching and understanding. At present the cadaver to student ratio is 1:25 which should be $1: 10$. Because of this reason it is often seen that most of the students never get a chance to dissect which adversely affects the anatomy teaching. Increasing the cadaver donation worldwide might be a solution to the insufficiency of cadavers but people willing to donate the bodies are negligible or too small which causes undersupply of cadavers to the medical colleges. $^{4,5}$ In 1948, the Anatomy Act was passed in India. This act allows the bodies to be donated by donors and bodies are to be claimed for medical and research purpose if there was no claim to one's body within a 48 - hour timeframe. The act was further amended by state legislative council in 2000 to permit donation of body before death. 6

Body donation is an informed and selfless act of giving one's body for the purpose of medical, education and research after the death. Though the concept of body donation evolved over centuries, in India it is still in primitive stages. ${ }^{2}$

\section{Number of Faculties Willing / Unwilling for Body Donation}

From our study it was observed that $21.7 \%$ male \& $3.7 \%$ female faculties from medical colleges, $11 \%$ male and $5.71 \%$ female faculties from dental colleges and $25 \%$ male and $10 \%$ female faculties from ayurvedic colleges were willing for body donation. Umit s (2004) reported that anatomy teachers were generally in favour of donation with $86.5 \%$ especially of organs alone $52.7 \%$. Only $15.7 \%$ were willing for body donation. ${ }^{7}$ Prachi et al. 2013 observed that though doctors unanimously comply with the importance of dissection in anatomy teaching and understanding they themselves are not 
keen on donating their bodies. Only $29 \%$ of female doctors and $52 \%$ of male doctors were willing to donate their bodies. ${ }^{4}$ Rokade SA Gaikwad A (2012) stated that, though health care professionals were more aware of body donation programs than general population, only $44.9 \%$ of health care professionals were willing to donate their bodies for anatomical education. ${ }^{1}$ Ballala $\mathrm{K}$, et al 2011 in a study among medical professionals also showed that only $22 \%$ physicians were willing to donate their bodies for medical education. ${ }^{8}$ Saha Anubha stated that merely $2 \%$ of doctors in their study were willing to donate their bodies for dissection purpose. ${ }^{9}$ Hiwarkar MP 2016 reported that merely $15 \%$ of the staff members were willing for body donation. From various studies carried out to estimate the number of doctors willing for body donation it was being observed that, medical professionals were reluctant about the body donation. ${ }^{10}$

\section{Reasons for Willingness and Unwillingness for Body Donation}

There are many reasons for unwillingness towards body donation. These are demographic and socio-economic factors like age, sex, education, race, ethnicity, occupation, and income, attitude about religion, spirituality, marital status, or member of dependents. ${ }^{1}$ In our study, $96 \%$ of faculties from medical colleges, $92 \%$ from dental colleges, and $89 \%$ ayurvedic faculties were not willing to donate their bodies for dissection purpose because they had an awful experience in the dissection hall. They had witnessed the dishonoured condition of cadavers in dissection hall. $96 \%$ of faculties from medical college, $92 \%$ dental faculties and $90 \%$ ayurvedic faculties stated that to get dissected on the table was an atrocious feeling. They themselves had seen the neglect of corpse in the hall, cadavers kept in formalin tank, pulled and dragged to the dissection table and they also had seen the rags of their bodies, they didn't want such type of behaviour to happen with their bodies. The attachment and love for one's body is the reason behind this. In addition to these factors, faculties were also of the opinion that cadavers were not disposed of properly and also disrespected by the students and themselves. Prachi et al. stated that foremost reason for refusal to donate is anxiety of disrespectful behaviour observed towards cadavers, and improper handling and disposal of the part of the cadaver by the anatomy staff features a psychological meaning. ${ }^{4}$ A study among Turkish anatomist reported that $63.9 \%$ wouldn't consider themselves to donate their bodies as they weren't prepared. Umit S (2004) doctors were against donation because of psychological reasons. The other reasons cited were unacceptability for getting dissected by colleagues and the unacceptability of donation by family. ${ }^{7}$ Ballala K, Shetty A (2011) in a study among medical professionals showed that $85 \%$ believed that donated bodies were misused. ${ }^{8}$

But some of the doctors were of the opinion that in this era of evolving technology, competent software's, and simulation were enough to learn anatomy and there was no need of cadaveric dissection and so they were against body donation. Among the faculties who were willing for body donation, $98 \%$, $98 \%, 96 \%$ of medical, dental, ayurvedic faculties respectively wanted to be useful to the medical sciences after death and express their gratitude to the medical profession. ${ }^{1}$

\section{Measures to Improve the Attitude of Medical Professionals toward Body Donation}

Changing person's attitude can change his behaviour. The cognitive components of attitude are more fundamental and more constant over time and more closely connected to the basic values. Behavioural attitudes are manifestations of underlying cognitive and affective attitudes. To create awareness among the population is one of the responsibilities of the medical professionals. For this they should have positive attitude towards body donation One of the ways to change the attitude of doctors is to imbibe in them the practices of respecting and honouring the cadavers from the commencement of medical course session as in Korea and Thailand.12 Medical council of India with the introduction of competency based medical education since 2019 added two competencies in the curriculum, competency no AN82.2 from volume 1 UG curriculum, 'Demonstrate respect and follow the correct procedure when handling cadaver and other biologic tissue' and module no 1.5 from ATCOM module 'The cadaver as first teacher' which deals with the ethical aspect of cadaveric dissection will help to change the attitude of Indian medical graduate towards body donation. ${ }^{13,14}$ Practices like cadaveric ceremonies, oath taking ceremonies during first phase of medical under graduation should be routinely conducted which will provide an ethical framework in the dissection hall as well as imbibe in them the values of professionalism, ethics and empathy.

\section{CONCLUSIONS}

The success of body donation programs depends upon the ability of health care professionals in motivating the society for voluntary body donation. Negative attitude of medical fraternity towards body donation may interfere with this role. Developing the practices of respecting and honouring the cadavers, from the very beginning of career will help to change the attitude of doctors towards body donation. Competency no AN82.2 from volume 1 UG curriculum, module no 1.5 from ATCOM module will help to change the attitude of medical students.

Data sharing statement provided by the authors is available with the full text of this article at jemds.com.

Financial or other competing interests: None.

Disclosure forms provided by the authors are available with the full text of this article at jemds.com.

\section{REFERENCES}

[1] Rokade SA, Bahetee BH. Body donation in India: a review. International Journal of Research in Medical Sciences 2013;1(3):36-41.

[2] Jadhav SD, Zambre BR. Body donation: a gift today for better tomorrow-review article. Anatomica Karnataka 2012;6(1):57-61.

[3] Ranjan R, Jain A, Jha K. Evaluation of awareness of voluntary body donation among hospital visiting populatioin Ujjain. International Journal of Medical and Applied Sciences 2014;3(1):116-21. 
[4] Aneja PS, Bansal S, Sood KS, et al. Body donation-a dilemma among doctors. Journal of Evolution of Medical and Dental Sciences 2013;2(16):2585-94.

[5] Saritha DS, Rao V, Sumangala, et al. Voluntary body donation the gift that lives on forever. International Journal of Advancements in Research and Technology 2012;1(5):273-80.

[6] Bombay Act No. XI of 1949. The Anatomy Act 1949. http://bombayhighcourt.nic.in/libweb/acts/1949.11.pd accessed on 10th October 2020.

[7] Şehirli ÜS, Saka E, Sarikaya Ö. Attitudes of Turkish anatomists toward cadaver donation. Clin Anat 2004;17(8):677-81.

[8] Ballala K, Shetty A, Malpe SB. Knowledge, attitude and practices regarding whole body donation among medical professionals in a hospital in India. Anat Sci Educ 2011;4(3):142-50.
[9] Saha A, Sarkar A, Mandal S. Body donation after death: the mental setup of educated people. J Clin Diagn Res 2015;9(6):AC05-9.

[10] Hiwarkar MP, Kulkarni YR, Hiwarkar MP. Voluntary body donation-a survey of awareness among teaching staff of Medical Colleges in Nagpur. Indian Journal of Clinical Anatomy and Physiology 2016;3(3):318-21.

[11] Rokade SA, Gaikawad AP. Body donation in India: Social awareness, willingness and associated factors. Anat Sci Educ 2012;5(2):83-9.

[12] Park JT, Jang Y, Park MS, et al. The trend of body donation for education based on Korean social and religious culture. Anat Sci Educ 2011;4(1):33-8.

[13] UG-Curriculum-Vol-I.pdf. [cited 2020 Oct 13]. https://wbuhs.ac.in/wp-content/uploads/2019/01/UGCurriculum-Vol-I.pdf

[14] Attitude, Ethics and Communication (AETCOM). Competencies for the Indian Medical Graduate. Graduate Med Educ Regulations 2017. 